\title{
The 2015 legislative elections in Portugal: A constitutional analysis
}

Maria Manuela Silva Magalhaes*

Andre Matos

Suggested Citation

Global Journal of Sociology: Current Issues 7

Abstract 
1. Introduction

2. The Emergence of the Current Portuguese Constitution 
modus faciendi
sui generis

3. The political system and the system of government under the current Portuguese Constitution

3.1. Elements of the parliamentary system

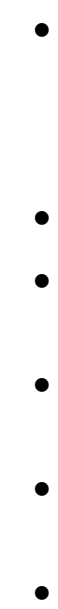

3.2. Elements of the presidential system: 
4. The Legislative Elections of October $4^{\text {th }}, 2015$ 


\section{Final Considerations}




\section{References}

Direito constitucional e teoria da constituicao

Introducao a ciência política

Nocoes de direito constitucional e ciência política

Direito constitucional 